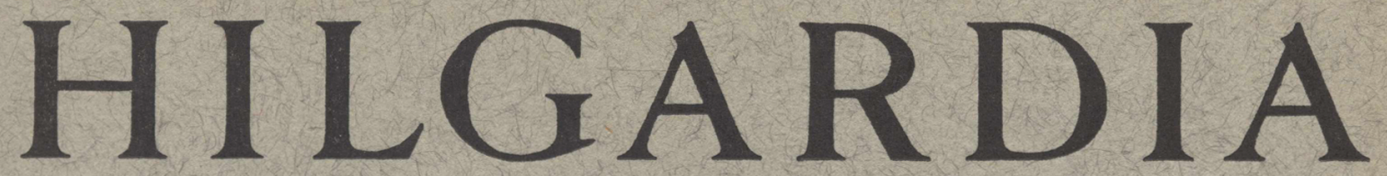

A Journal of Agricultural Science Published by the California Agricultural Experiment Station

\title{
PYTHIUM ROT OF PINK AND YELLOW CALLA CORMS AND ITS CONTROL
}

\author{
C. M. TOMPKINS
}


This paper reports investigations on a rot of pink and yellow calla corms occurring in the Santa Cruz region of California. Discussed are symptoms, associated environmental factors, causal organism, and control. 


\begin{tabular}{lll}
\hline Vol. 20 & SEPTEMBER, 1950 & No. 10 \\
\hline
\end{tabular}

\section{PYTHIUM ROT OF PINK AND YELLOW CALLA CORMS AND ITS CONTROL ${ }^{1}$}

\section{M. TOMPKINS ${ }^{2}$}

IN THE Santa Cruz region of California, pink calla (Zantedeschia rehmannii Engler) and yellow calla ( $Z$. elliottiana Engler) corms are frequently infected through cutting and bruising during harvesting operations. Early symptoms of the disease may become visible within a day or two after the corms are wounded, and the disease may spread rapidly within the corms in the presence of favorable air temperatures and moisture. Severe losses have been sustained by many nurseries in recent years.

A brief discussion of the symptoms, cause, and control of the disease is presented in this paper.

\section{SYMPTOMS OF THE DISEASE}

Under conditions favoring natural infection, the first visible symptom of the disease on pink and yellow calla corms, after harvest, consists of small to large, irregular-shaped, shallow, water-soaked lesions which, in their lateral spread, quickly destroy the thin skin (plate 1). One or more lesions may occur on the same corm, and often they coalesce to form larger lesions. Infection may rapidly involve most of the skin of both flowering-sized corms and small corms or offsets attached thereto. Destruction of the skin causes the creamy-white flesh of the corm to turn pink on exposure to the air.

Within a few days, infection may spread deeply into the flesh of the corm from the watery surface lesions, producing small to large, irregular-shaped, light-gray lessions which are sharply delimited, sometimes by a narrow, marginal, black line, from the adjoining healthy tissue. Internal lesions are irregular in shape, soft to firm, rubbery, watersoaked to dry, and odorless plate 2 , top, center), in marked contrast to healthy tissue (plate 2 , bottom). On the surface of the corms, older lesions become dry, dark-brown to black in color, and may be slightly sunken (plate 3, top, center), in marked contrast to the light-tan skin of healthy corms (plate 3, bottom). Infected corms may be partially to completely destroyed.

The disease is favored in its development and spread by a humid atmosphere and by the moisture contained in the soil particles adhering to the

${ }^{1}$ Received for publication February 23, 1950.

- Associate Plant Pathologist in the Experiment Station, Berkeley. 
skin of the corms prior to cleaning. Air temperatures of $50^{\circ} \mathrm{F}$. or higher are favorable to infection; lower temperatures retard the disease.

\section{THE CAUSAL FUNGUS, PYTHIUM ULTIMUM}

Naturally infected pink and yellow calla corms, of different sizes and in various stages of decay, were collected in the field and in storage at Santa Cruz in November and December of 1946 and 1947. Under aseptic conditions in the laboratory, small fragments of diseased tissue, taken from the advancing edge of external and internal lesions next to healthy tissue, were planted on poured plates of malt-extract agar. Isolations consistently yielded a fungus which was identified as Pythium ultimum Trow. ${ }^{3}$ The fungus was also isolated in 1948 and 1949 from pink and yellow ealla corms which had been stored one to three months.

Sound, healthy, pink and yellow calla corms, averaging two inches in diameter, were used in studies on pathogenicity. All corms were thoroughly washed in tap water and rinsed in distilled and sterile distilled water, after which they were dried on paper towels. Each of 20 glass-covered moist chambers was lined with sterile filter paper and moistened with sterile distilled water to provide a humid atmosphere. In each moist chamber, one healthy corm was placed on the top of each of four inverted glass preparation dishes, arranged so that the corms did not touch each other and, at the same time, were kept dry.

Inoculum was prepared by growing two isolates of the fungus, one from an infected pink and one from an infected yellow calla corm, on poured plates of malt-extract agar. When ready for use, usually after four to five days, the agar was cut into blocks $1 / 2^{\prime \prime} \times 1 / 2^{\prime \prime} \times 3 / 16^{\prime \prime}$, one of which, after inverting, was then placed on the top surface and in firm contact with the skin of each corm. In this manner, 24 pink calla corms were treated with the pink-calla isolate and 24 yellow calla corms with the isolate from that host. Twelve corms in each group were then wounded by making small, shallow incisions through the blocks of agar inoculum with a flamed scalpel. For controls, 16 pink calla and 16 yellow calla corms were treated in a similar manner except that blocks of sterile malt-extract agar were placed on the top surface of the corms, eight of each group being wounded. Each agar block in the inoculated and control series, as well as most of the top surface of each corm, was then covered with a pad of sterile absorbent cotton which had previously been saturated with sterile distilled water. All inoculated and control corms were held at an air temperature of $60^{\circ}$ to $65^{\circ} \mathrm{F}$. for the duration of the tests.

No pink or yellow calla corms which had been inoculated without wounding showed any signs of infection after 21 days. They were sound and healthy. Of 12 pink calla corms inoculated by wounding, 11 corms developed initial symptoms of infection after six days, at first involving primarily the skin and adjacent tissue, but extending deeply into the tissues after 11 days. Daily examination of the 12 wounded yellow calla corms revealed that nine of them were slightly infected after five days and severely infected after 14

\footnotetext{
${ }^{3}$ The writer is indebted to J. T. Middleton, Division of Plant Pathology, Citrus Experiment Station, Riverside, for confirming the identification of the causal organism.
} 
days. All control corms remained healthy. The fungus was reisolated from each infected corm and proved to be identical with the original isolate. The reisolates from pink and yellow calla corms proved highly pathogenic.

In cross-inoculation tests, the pink-calla isolate proved pathogenic to yellow calla corms and the yellow-calla isolate infected pink calla corms. In each case, four inoculated corms became infected in five to six days. Apparently, the two isolates of the fungus used in these tests are identical with regard to their infective capacity.

All artificially-infected corms exhibited symptoms identical with those of naturally-infected corms.

\section{CONTROL OF THE DISEASE}

Experimental tests indicate conclusively that the storage rot of pink and yellow calla corms, caused by Pythium ultimum, can be controlled by care in harvesting, sanitation, and chemical treatment.

As indicated in the studies on pathogenicity, the fungus is a wound parasite and apparently does not invade sound, healthy corms. If care is taken to avoid injuring the corms at harvest, then a minimum amount of infection may be expected. It is seldom that an injured corm fails to become infected, either in the field soon after digging or following removal to storage.

It is highly important to clean all corms soon after they are dug. This is done at tables in storage sheds and involves hand removal of the dead roots and adhering soil particles. As the debris is being cleared away, infected corms are easily detected by their black or water-soaked skin lesions and should be segregated from those which are healthy. At convenient intervals, cleaning may be discontinued while the lot of cleaned but infected corms is being treated. This involves excision of the decayed area or areas with a clean, sharp, paring knife, making the cut or cuts through adjoining healthy tissue. The knife is flamed in alcohol at frequent intervals. The cut surface is then covered with a thin layer of a mixture (equal parts by volume) of Spergon (tetrachloro-parabenzoquinone) and Celite 505 (a diatomaceous earth) held in a shallow container. This is done merely by inserting the wounded parts of each corm into the fungicide to a sufficient depth to insure coverage. Any excess dust can be removed by gentle tapping of the corm on the edge of the container. This dust serves a dual purpose: (1) Spergon gives fungicidal protection and (2) Celite 505 absorbs excess moisture on cut surfaces and accelerates wound-healing or suberization. By preparing this fungicidal dust as indicated above, the cost is reduced by almost one-half.

The surface of all corms is then dusted lightly with the Spergon mixture, applied with a small shaker or by means of a small hand duster. It is necessary to rotate the corms contained in small flats several times during this process in order to insure complete coverage. The dusted corms are then placed in clean, well-ventilated bulb trays, preferably one layer deep, or not more than two layers, and stored under cool temperature conditions until planting time.

In the control experiments conducted from 1945 to 1949, it is estimated that more than 10,000 pink calla and 50,000 yellow calla corms were sorted, of which about one-fourth to one-third of the stock was infected in some 
degree. No outstanding difference in susceptibility to infection between pink and yellow calla corms was noted in any season. Diseased specimens of each species showed slight to severe tissue involvement. Proper cleaning, excision of diseased tissue, and chemical dusting of all exposed surfaces of corms gave excellent control of the disease under conditions obtaining in commercial bulb-storage sheds.

\section{DISCUSSION}

Because of favorable soil and climatic conditions, the bulk of the acreage devoted to the culture of pink and yellow callas in the United States is concentrated in the Santa Cruz region of California. Individual plantings are usually small, ranging from less than one to several acres. These crops, propagated from both seeds and corms, are grown primarily for corm rather than for cut-flower production.

\section{Infection through Digging}

It is customary to dig the corms by hand late in the fall of each year, after the foliage has dried down and before the advent of the winter rains. Although care is taken to avoid injuring the corms when digging, frequently many of them are cut, bruised, and otherwise damaged in handling, thus exposing small to large, internal areas of unprotected tissues. Small corms, or offsets, often are separated prematurely from the old or parent corms, on which they are borne, by breakage, thus exposing additional large, unprotected areas of tissue. If these corms are dug when the soil is wet, due to late irrigation or early winter rains, inevitably they will be partially or completely covered with a thin to thick, wet layer of adhering soil particles, some of which may be in contact with the wounded surface. Infection may occur while the corms are still in the field after digging, immediately after their removal to bulb-storage sheds, or at any time during the storage period, which ranges from several weeks to several months where stock is held for planting purposes. If there is any appreciable delay in cleaning the corms after harvesting and storing, i.e., removing the old, dried roots and layers of soil adhering to the skin of the corms, then new infections may be initiated very quickly when moisture and air temperature conditions are favorable. The disease, if already present in corms after removal to storage, may continue to spread and may rapidly involve most or all of the internal tissue. Apparently air temperature in storage is less important than moisture in its effect on rate of spread and on the initiation of new infections. However, it has been observed that air temperatures of $32^{\circ}$ to $50^{\circ} \mathrm{F}$. are definitely less favorable to infection and rate of spread of the disease than those above $50^{\circ}$.

\section{Infection through Trimming}

In preparing the large, flowering-sized pink and yellow calla corms for shipment, it is customary to trim them after they are cleaned. This involves the removal of all offsets or small corms from the large or parent corm by cutting through the tissue at the point of attachment with a paring knife. Other offsets can be removed merely by applying slight pressure with the fingers. If a rough surface results from detachment of the offsets, either by cutting or mechanical breakage, then further excision is practiced. After 
trimming, the large corms are immediately packed, without chemical treatment, in wooden crates in single layers separated and cushioned by excelsior or shredded paper, and shipped to eastern buyers. During the winter and spring, this stock is then forced in pots or in beds in eastern greenhouses for flower production. It has been found that non-dusted corms frequently become infected after cleaning and trimming. Wound-healing proceeds at a much slower rate in lots of non-dusted than in lots of dusted calla corms. The disease may spread quickly in the crates while the corms are in transit, particularly if warm air temperatures prevail.

\section{Protection from Infection}

When small to large corms, reserved for planting stock, are dusted with the Spergon mixture immediately after cleaning, they are well protected from fungus infection, not only while in a dormant condition in storage but after being planted in the field in late winter or early spring. This fungicide protects the corms from rot while the new root system is being developed, and is especially valuable if frequent, heavy rains fall during that critical period.

\section{SUMMARY}

A rot of pink and yellow calla corms, prevalent at harvest time and in storage, occurs in the Santa Cruz region of California.

External symptoms of the disease consist of small to large, shallow, watersoaked lesions which destroy the skin of the corms. Old lesions are dry, darkbrown to black in color, and slightly sunken. Internally, small to large, soft to firm, water-soaked, light-gray lesions develop. The disease may partially or completely destroy the corms in a short time.

Moisture in the soil particles adhering to the skin and wounded areas of the corms after harvest, coupled with relatively high humidity and air temperatures of $50^{\circ} \mathrm{F}$. or above in storage, are the principal environmental factors favoring inception and spread of the disease.

The causal organism has been identified as Pythium ultimum Trow. Its pathogenicity was proved in laboratory tests. The fungus is a wound-parasite.

The disease can be controlled by avoidance of mechanical injury to the corms during harvest, prompt cleaning, excision of diseased tissue, dusting of all cut and exposed surfaces with a mixture of Spergon and Celite 505, and storing in well-ventilated bulb trays at an air temperature of $50^{\circ} \mathrm{F}$. or less when corms are held for planting stock. 


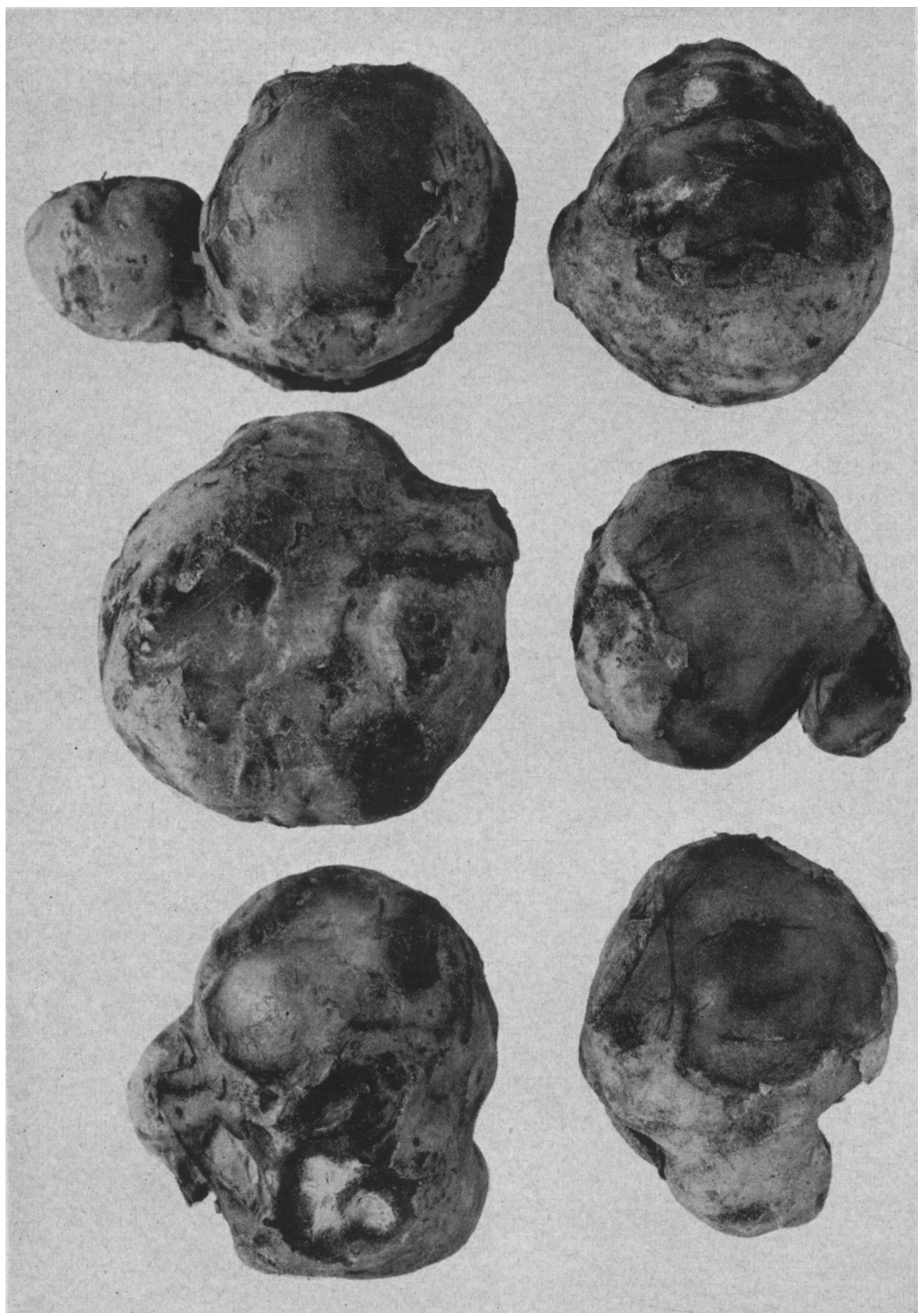

Plate 1. Natural infection of pink ealla corms by Pythium ultimum, showing irregularshaped, shallow, watersoaked lesions which destroy the skin. The creamy-white flesh of the corms turns pink on exposure to the air. 


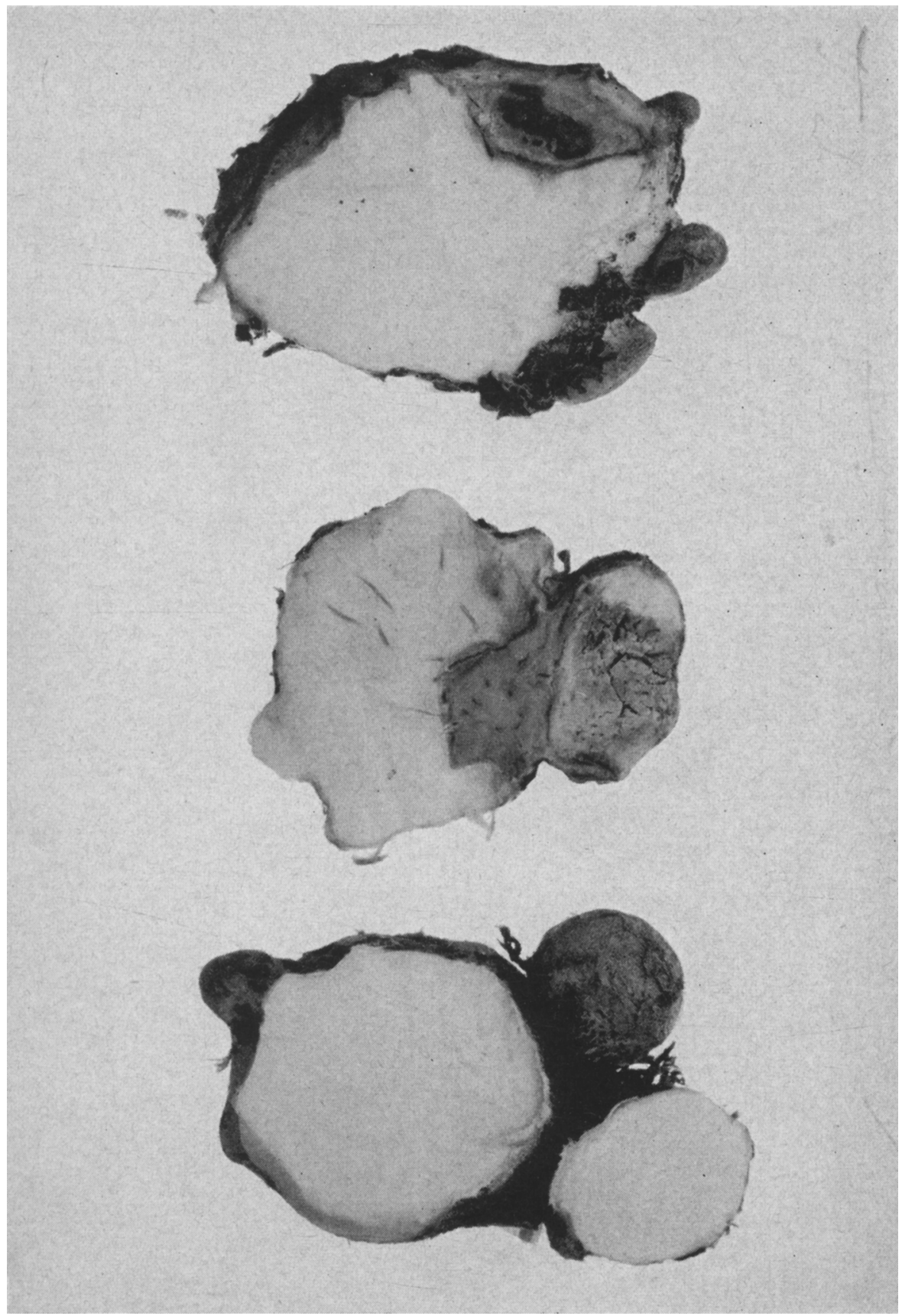

Plate 2. Natural infection of yellow calla corms by Pythium ultimum: top, center, corms showing internal light-gray lesions in cross section; bottom, healthy corm and off sets. 


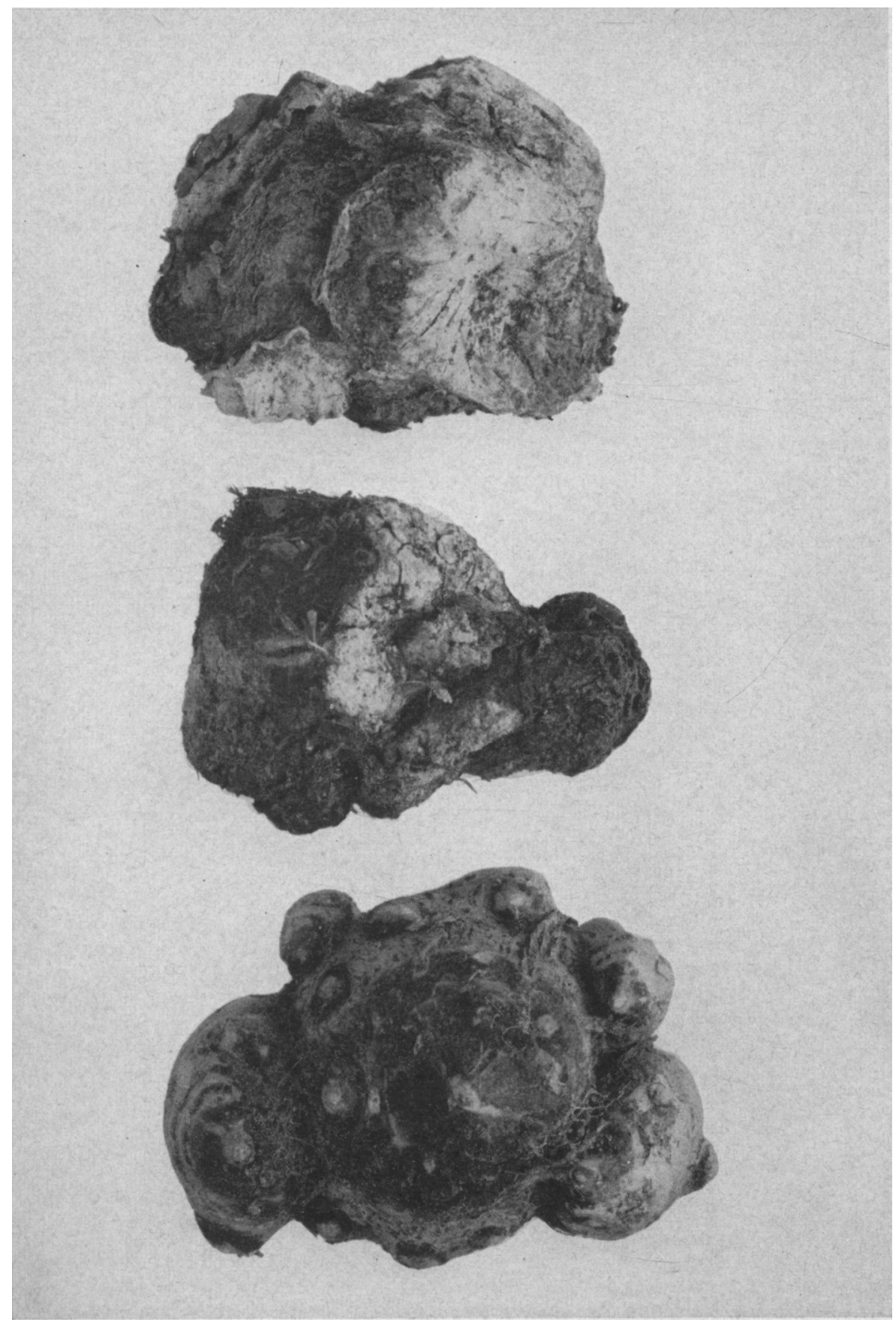

Plate 3. Natural infection of yellow calla corms by Pythium ultimum : top, center, irregularshaped, dark-brown to black, slightly sunken external lesions; bottom, healthy corm. 
The journal Hilgardia is published at irregular intervals, in volumes of about 600 pages. The number of issues per volume varies.

Subscriptions are not sold. The periodical is sent as published only to libraries, or to institutions in foreign countries having publications to offer in exchange.

You may obtain a single copy of any issue free, as long as the supply lasts; please request by volume and issue number from:

\section{Publications Office \\ College of Agriculture \\ Berkeley 4, California}

The limit to nonresidents of California is 10 separate issues on a single order. A list of the issues still available will be sent on request.

In order that the information in our publications may be more intelligible it is sometimes necessary to use trade names of products or equipment rather than complicated descriptive or chemical identifications. In so doing it is unavoidable in some cases that similar products which are on the market under other trade names may not be cited. No endorsement of named products is intended nor is criticism implied of similar products which are not mentioned. 